\title{
Control of Soilborne Plant Pathogens by Incorporating Fresh Organic Amendments Followed by Tarping
}

\author{
Wim J. Blok, Jan G. Lamers, Aad J. Termorshuizen, and Gerrit J. Bollen
}

First, third, and fourth authors: Laboratory of Phytopathology, Wageningen University, P.O. Box 8025, 6700 EE Wageningen, the Netherlands; second author: Applied Research for Arable Farming and Field Production of Vegetables, P.O. Box 430, 8200 AK Lelystad, the Netherlands.

Current address of W. J. Blok and A. J. Termorshuizen: Biological Farming Systems Group, Wageningen University, Marijkewey 22, 6709 PQ Wageningen, the Netherlands.

Accepted for publication 9 November 1999.

\begin{abstract}
Blok, W. J., Lamers, J. G., Termorshuizen, A. J., and Bollen, G. J. 2000. Control of soilborne plant pathogens by incorporating fresh organic amendments followed by tarping. Phytopathology 90:253-259.

A new method for the control of soilborne plant pathogens was tested for its efficacy in two field experiments during two years. Plots were amended with fresh broccoli or grass (3.4 to $4.0 \mathrm{~kg}$ fresh weight $\mathrm{m}^{-2}$ ) or left nonamended, and covered with an airtight plastic cover $(0.135 \mathrm{~mm}$ thick) or left noncovered. In plots amended with broccoli or grass and covered with plastic sheeting, anaerobic and strongly reducing soil conditions developed quickly, as indicated by rapid depletion of oxygen and a decrease in redox potential values to as low as $-200 \mathrm{mV}$. After 15 weeks, survival of Fusarium oxysporum f. sp. asparagi, Rhizoctonia solani, and
\end{abstract}

ABSTRACT

In intensive farming systems with narrow rotations, soilborne plant pathogens frequently reach high inoculum densities, thus threatening the profitability of crops. A crucial factor in the management of diseases caused by these pathogens is to reduce their inoculum level below the critical threshold level before a susceptible crop is planted. Since the 1950 s, chemical soil disinfestation commonly has been used for this purpose. In recent years, however, it has become more widely recognized that chemical soil disinfestation is incompatible with sustainable agriculture and its use increasingly is becoming restricted. As a consequence, the interest in alternatives has increased. For some situations, these alternatives are already available for commercial application. Soil solarization, either alone or in combination with organic amendments $(4,6)$, and soil flooding (19) are effective alternatives for control of soilborne plant pathogens in specific areas or under specific conditions. Soil solarization is effective in subtropical areas only, where solar radiation is sufficiently intensive to create lethal soil temperatures. Flooding is limited to fields with a suitable hydraulic conductivity and a readily available source of irrigation water. These limitations reveal that there is a need for the development of control measures for many agricultural soils in the temperate zones of the world.

It has been well-documented that survival of many plant pathogens is strongly reduced under anaerobic soil conditions. The exact mechanism is not clear, but lack of oxygen, the accumulation of toxic products resulting from anaerobic decomposition processes, and biocontrol by anaerobic microorganisms have been implicated as critical factors $(2,19)$. In the field, anaerobic conditions

Corresponding author: W. J. Blok; E-mail address: wim.blok@medew.fyto.wau.nl

Publication no. P-2000-0114-01R

(c) 2000 The American Phytopathological Society
Verticillium dahliae in inoculum samples buried $15 \mathrm{~cm}$ deep was strongly reduced in amended, covered plots in both experiments. The pathogens were not or hardly inactivated in amended, noncovered soil or nonamended, covered soil. The latter indicates that thermal inactivation due to increased soil temperatures under the plastic cover was not involved in pathogen inactivation. The results show the potential for this approach to control various soilborne pathogens and that it may serve as an alternative to chemical soil disinfestation for high-value crops under conditions where other alternatives, such as solarization or soil flooding, are not effective or not feasible.

Additional keywords: anaerobiosis, biological control, biological soil disinfestation, cultural control.

develop when oxygen consumption, mostly by the soil microflora, exceeds resupply of oxygen by diffusion from the atmosphere. This happens frequently in the center of soil crumbs, especially after incorporation of large quantities of decomposable organic material or after heavy rainfall (2). Pathogen kill, which eventually occurs in these anaerobic microsites, generally does not sufficiently decrease the inoculum density due to the limited extent and duration of the anaerobic conditions. We have attempted to establish general soil anaerobiosis by increasing microbial respiration through the incorporation of readily decomposable organic amendments into moist soil and by reducing the resupply of oxygen by covering the soil with ensilage plastic with low oxygen-permeability characteristics. After encouraging results in preliminary studies under laboratory conditions, two field experiments were conducted to determine the prospects for this approach to control persistent soilborne plant pathogens.

\section{MATERIALS AND METHODS}

Preparation of inocula and testing of pathogen survival. $\mathrm{Fu}$ sarium oxysporum (Schlechtend.) emend. W.C. Snyder \& H.N. Hans. f. sp. asparagi (S.I. Cohen \& Heald) strain CWB1 was originally isolated from asparagus roots in the Netherlands. For preparation of inoculum, the strain was grown in malt extract broth for 7 days at $25^{\circ} \mathrm{C}$. After comminuting the cultures in a blender, the slurry was centrifuged at $3,400 \times g$ for $30 \mathrm{~min}$, and the precipitate was resuspended in sterile distilled water and added to talcum powder $(1: 2, \mathrm{wt} / \mathrm{wt})$. This mixture was dried with forced air for 14 days, after which the talcum powder was passed through a sieve with 0.36 -mm openings. Samples of $F$. oxysporum f. sp. asparagi consisted of $\approx 15 \mathrm{~g}$ of talcum inoculum in nylon bags. Survival was tested by plating 10 -fold dilutions of the talcum inoculum in $0.1 \%$ water agar on Komada's medium (8) with five replicate $0.25-\mathrm{ml}$ aliquots per dilution. 
Rhizoctonia solani Kühn anastomosis group 3 (AG-3) strain 3R41 was originally isolated from a potato plant in the Netherlands. Inoculum was produced by growing the strain for 4 weeks at $20^{\circ} \mathrm{C}$ on sterilized perlite ( 2 to $5 \mathrm{~mm}$ diameter) soaked in a solution containing $1.5 \%$ malt extract and $0.1 \%$ peptone. Samples consisted of narrow nylon bags with a minimum of 100 perlite kernels colonized by $R$. solani. Survival was tested by placing 64 perlite kernels of each sample on $1.2 \%$ water agar amended with oxytetracyclin at $50 \mathrm{mg} \mathrm{liter}^{-1}$ (16 kernels per 9-cm petri dish). After 1 or 2 days at $20^{\circ} \mathrm{C}$, outgrowth of $R$. solani was rated on a 0 to 3 scale, where $0=$ no outgrowth, $1=1$ to 7 hyphae per perlite kernel, $2=8$ to 35 hyphae per perlite kernel, and $3=>35$ hyphae per perlite kernel. In earlier experiments (J. G. Lamers, unpublished data), a highly significant correlation was observed between vitality of $R$. solani inoculum rated according to this scale and stem infection of potato plants by $R$. solani. A germination index (GI) was calculated as GI $=100 \times[(0 \times$ number of kernels with rating 0$)+$ $(1 \times$ number of kernels with rating 1$)+(2 \times$ number with rating 2$)+$ $(3 \times$ number with rating 3$)] /(3 \times$ total number of kernels $)$.

Verticillium dahliae Kleb. inoculum for the 1994 field experiment was prepared by milling air-dried dead potato stems that were densely covered with microsclerotia of $V$. dahliae to a powder. This powder was put at one end of a small PVC tube $(1 \mathrm{~cm}$ diameter, $4 \mathrm{~cm}$ long) filled with silver sand and closed at both ends with nylon gauze with 10- $\mu$ m openings. In 1995, soil was collected from an experimental field heavily infested with $V$. dahliae (clay, $\mathrm{pH}-\mathrm{KCl} 7.2,2.9 \%$ organic matter), air-dried, ground and mixed thoroughly, and put into nylon bags (100 ml per bag). At the end of the exposure period, the samples were recovered, airdried ( 2 weeks at room temperature), and ground to pass through a 2-mm sieve. Survival was tested following a slightly modified protocol of Harris et al. (5). Whole samples (1994) or $12.5 \mathrm{~g}$ of air-dried soil (1995) were wet-sieved over sieves with openings of 106 and $20 \mu \mathrm{m}$, respectively. The residue on the $20-\mu \mathrm{m}$ sieve was collected with $25 \mathrm{ml}$ (1994) or $50 \mathrm{ml}$ (1995) of $0.08 \%$ water agar, and 10 replicate $0.8-\mathrm{ml}$ aliquots were plated on modified soil extract agar (5). The plates were left open for $15 \mathrm{~min}$ in a laminar airflow cabinet to dry. After 4 weeks in the dark at $22^{\circ} \mathrm{C}$, the surfaces of the plates were washed under running tap water, and the plates were assessed under a dissecting microscope for the number of colonies of $V$. dahliae formed in the agar.

Soil physical and chemical parameters. Oxygen concentration of the soil atmosphere was determined by extracting soil atmosphere from a $10-\mathrm{ml}$ gas-diffusion chamber with a syringe. The gas-diffusion chamber consisted of a piece of PVC tubing $(1.6 \mathrm{~cm}$ diameter, $5 \mathrm{~cm}$ long) that was open at the bottom and closed with a butylrubber stopper at the top. The rubber stopper was pierced by copper tubing $(1.0 \mathrm{~mm}$ internal diameter $)$ that stood $\approx 5 \mathrm{~cm}$ above the soil surface. The copper tube was fitted at the top with a small piece of polyethylene tubing in which a metal pin was pushed for airtight closure. First, a 5-ml air sample was extracted and discarded, then a 10-ml air sample was extracted and injected into an oxygen analyzer (570A; Servomex, Crowborough, East Sussex, U.K.).

The redox potential of the soil was measured with platinum $(\mathrm{Pt})$ electrodes (TFDL, Wageningen, the Netherlands) and a glass calomel reference electrode (Schott Geräte, Hofheim, Germany). The Pt electrodes were inserted into soil to the desired depths at the start of the experiment and remained in the soil during the whole experimental period. The reference electrode was inserted into moist soil prior to a measurement. Redox potentials were expressed as $E_{h}$ values by adding $247 \mathrm{mV}$ to the measured potentials (22).
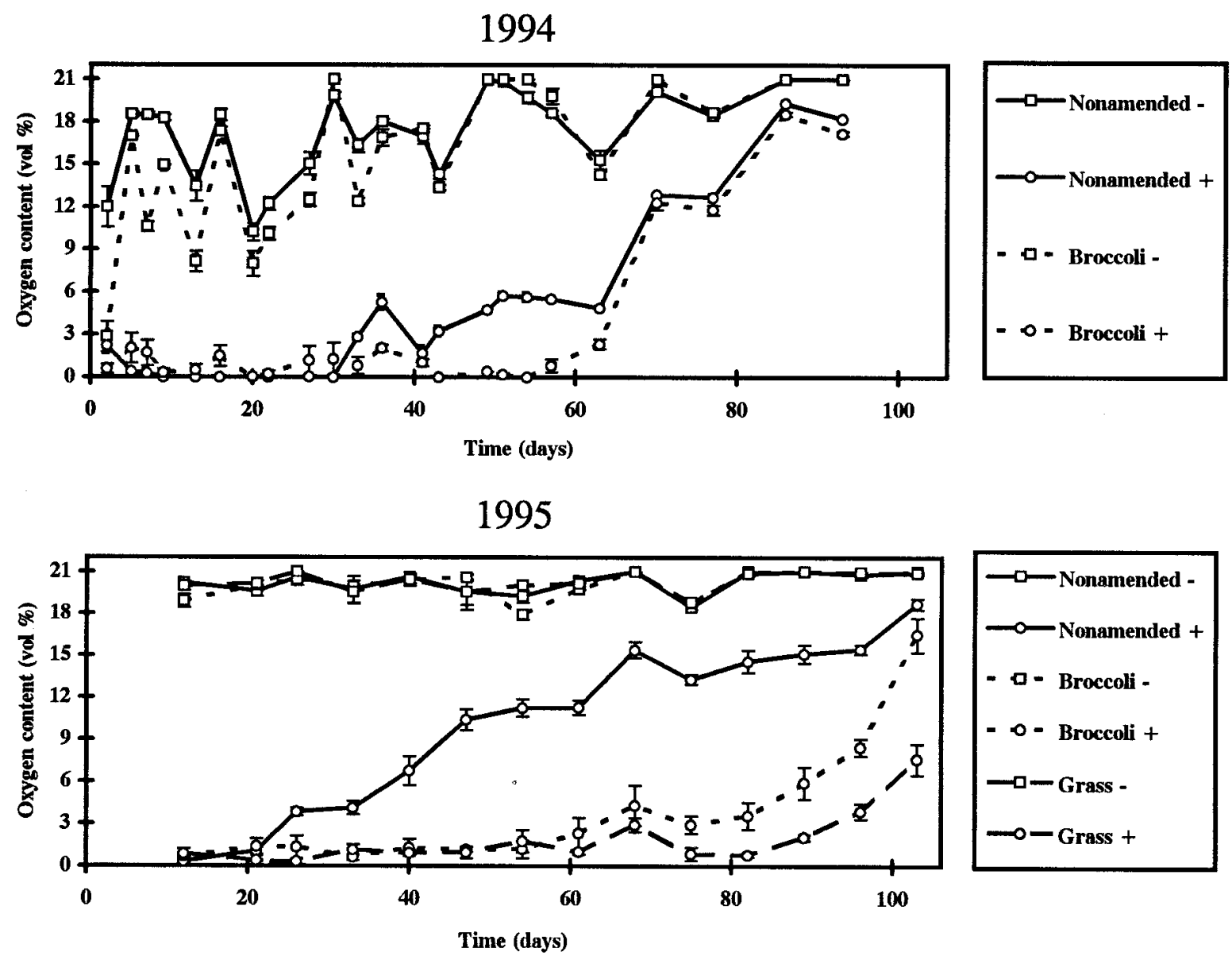

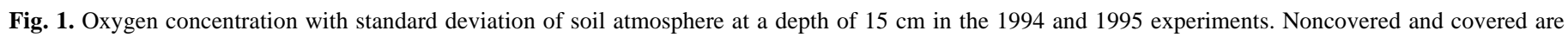
indicated by - and + , respectively. 
Soil and air temperature data were collected with thermocouples connected to a datalogger (SQ 32-16u, Grant, Cambridge, U.K.). The soil physical and chemical parameters were determined at a depth of $15 \mathrm{~cm}$ and at least $1.5 \mathrm{~m}$ from the border of the plot to avoid border effects. The air temperature was recorded at heights of 10 and $150 \mathrm{~cm}$. Temperature was recorded every hour; redox potential and oxygen concentration were determined two or three times per week.

Field experiment, 1994. In 1994, a field experiment was performed on a loamy sand ( $\mathrm{pH}-\mathrm{KCl} 6.1,3.1 \%$ organic matter) at the experimental farm Meterikse Veld at Horst, Province of Limburg, the Netherlands. On 18 June, fertilizer was applied in amounts of $135 \mathrm{~kg}$ of $\mathrm{N}, 240 \mathrm{~kg}$ of $\mathrm{K}_{2} \mathrm{O}$, and $160 \mathrm{~kg}$ of $\mathrm{MgO} \mathrm{ha}{ }^{-1}$. The experiment had a randomized complete block design with factorial combinations of two plastic-cover treatments and three organicamendment treatments in three blocks. The plots were $4 \times 4.5 \mathrm{~m}$, of which the inner $1.5 \times 1.5 \mathrm{~m}$ was used to bury pathogen samples and determine soil physical and chemical characteristics.

The tarping treatments were (i) noncovered and (ii) application of a plastic cover. The plastic cover used was Hytileen (Klerks Plastic Industrie, Noordwijkerhout, the Netherlands), a plastic film, $0.135 \mathrm{~mm}$ thick, consisting of three layers of polyethylene strengthened with ethylene vinyl acetate with a black and a white side, which is generally used for ensiling because of its relatively low permeability to oxygen. The plastic cover was used with the black side up because this results in higher soil temperatures than when the white side is up. Although transparent plastic cover would have resulted in even higher soil temperatures, it was not used because it would also allow growth of some weeds and algae under the plastic, resulting in oxygen production.

The organic amendment treatments were (i) nonamended (control), (ii) broccoli (Brassica oleracea L. convar. botrytis (L.) Alef. var. cymosa Duch.), and (iii) perennial ryegrass (Lolium perenne L.). For the broccoli treatment, 4-week-old plants (cv. Marathon) were planted on the experimental plots on 10 June and grown for 5 weeks. At the time of incorporation, the biomass was estimated (by weighing randomly collected samples) to be $3.8 \mathrm{~kg}$ fresh weight $\mathrm{m}^{-2}(0.5 \mathrm{~kg}$ oven dry-weight $\mathrm{m}^{-2}$ ). For the grass treatment, freshly mown grass was supplied from a production pasture and incorporated at a rate of $4.0 \mathrm{~kg}$ fresh weight $\mathrm{m}^{-2}\left(0.8 \mathrm{~kg}\right.$ oven dry-weight $\left.\mathrm{m}^{-2}\right)$.

On 11 July, the amendments were applied, and all plots were rototilled to a depth of 20 to $25 \mathrm{~cm}$. On 12 July, duplicate samples of $F$. oxysporum f. sp. asparagi and single samples of $R$. solani and $V$. dahliae were buried in all plots at a depth of $15 \mathrm{~cm}$. The field was sprinkler irrigated overnight $(\approx 50 \mathrm{~mm})$ and plots were covered with the plastic tarp on 13 July (day 0). The edges of the cover were buried $\approx 10 \mathrm{~cm}$ deep.

To determine whether changes in soil physical and chemical parameters were associated with pathogen survival rates, four additional plots, each with a different treatment combination, were laid out in which soil physical and chemical parameters were measured (measurement plots). The four plots were a nonamended, noncovered plot; a nonamended, covered plot; a broccoli-amended, noncovered plot; and a broccoli-amended, covered plot. In each of these plots, three Pt electrodes, three gas-diffusion chambers, and two thermocouples were installed at a depth of $15 \mathrm{~cm}$. The holes in the plastic cover around the Pt electrodes and the copper tubes of the gas-diffusion chambers were closed with silicone sealant to minimize oxygen diffusion. In these plots, samples of the same pathogens were buried $15 \mathrm{~cm}$ deep, as described above.

During the experiment, the noncovered plots were sprayed once with a herbicide ( $250 \mathrm{~g}$ of simazine and $400 \mathrm{~g}$ of diuron in 600 liters of water per ha) to prevent weed growth and sprinkler irrigated

\section{4}
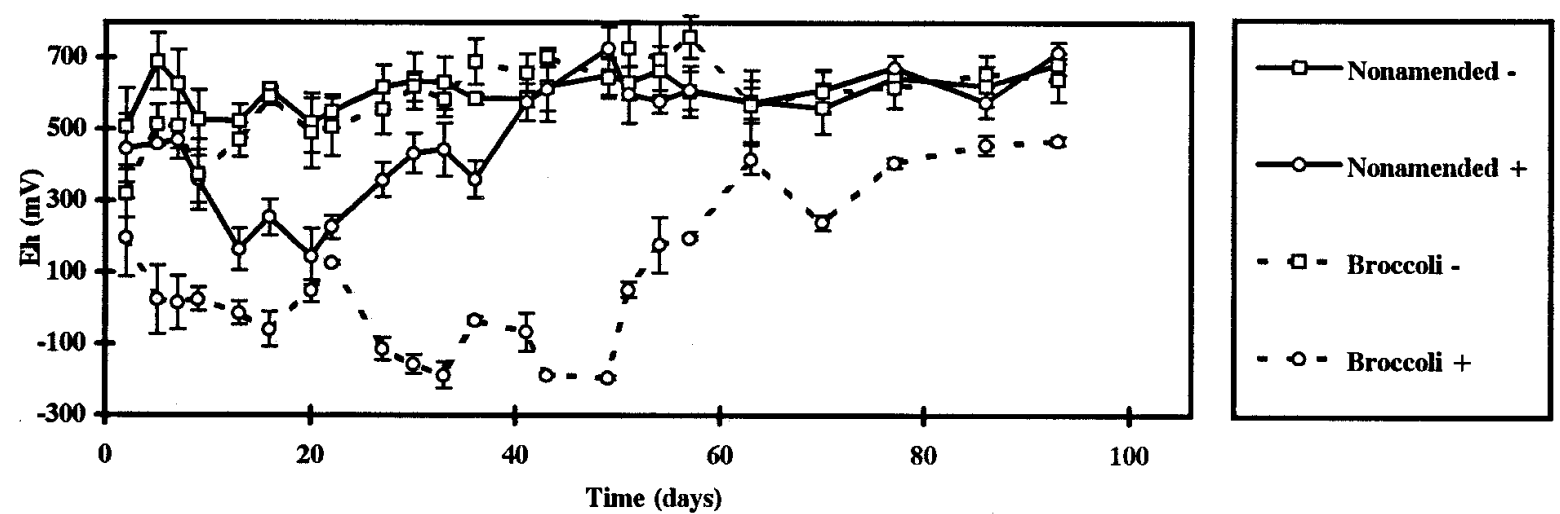

Time (days)

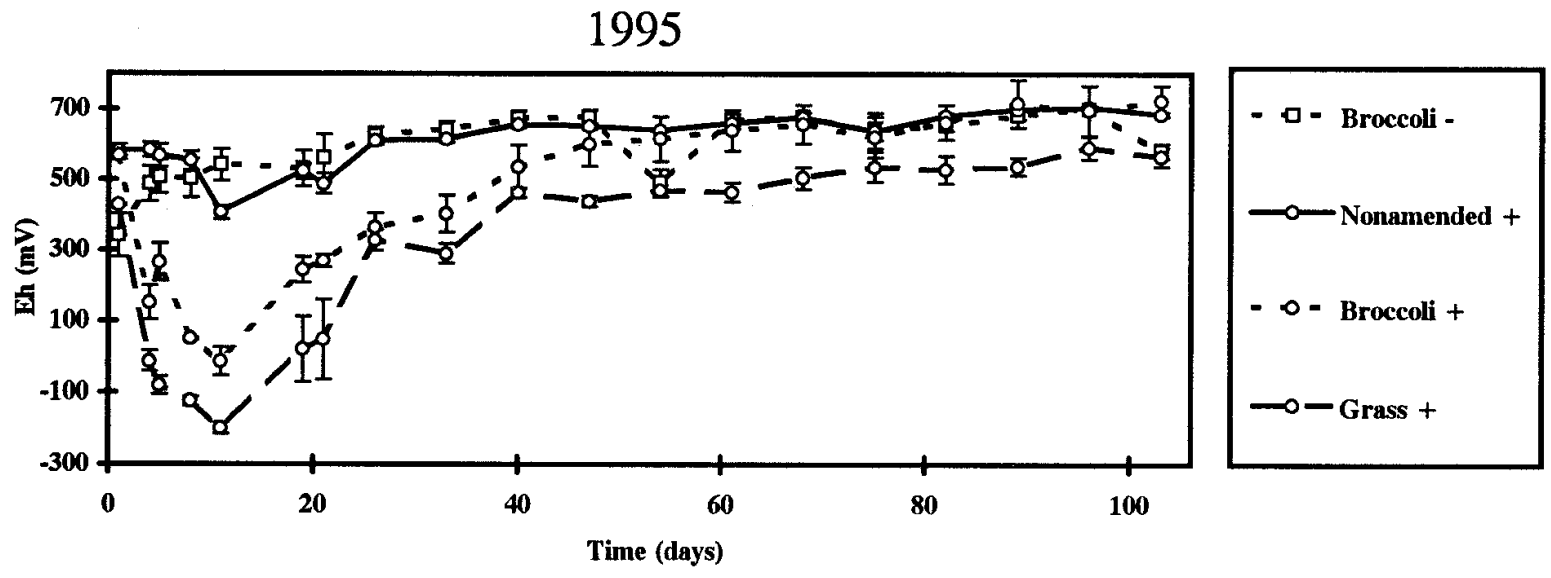

Fig. 2. Redox potential $\left(E_{h}\right)$ with standard deviation measured in field soil at a depth of $15 \mathrm{~cm}$ in the 1994 and 1995 experiments. Noncovered and covered are indicated by - and + , respectively. 
( $2 \mathrm{~mm}$ ) incidentally to prevent sand from blowing in dry periods. After 15 weeks, on 24 October, the plastic cover was removed, and the pathogen samples were recovered. Pathogen survival was determined as described above.

It is probable that not only pathogens but a whole array of soil organisms were affected by the combination of green amendments and plastic cover, which could affect soil suppressiveness to pathogens or the diseases they cause. To test this theory for one of the pathogens, $F$. oxysporum f. sp. asparagi, composite soil samples were prepared by mixing 10 samples from the upper $15 \mathrm{~cm}$ of each of the plots of the following treatment combinations: nonamended-noncovered, nonamended-covered, broccoli-noncovered, and broccoli-covered, all collected on the day the plastic cover was removed. The soil was mixed with talcum inoculum of $F$. oxysporum $\mathrm{f}$. sp. asparagi strain CWB1 to a density of $100 \mathrm{CFU} \mathrm{g}{ }^{-1}$ of dry soil, a density known to result in a low root-rot severity in nontreated soil (W. J. Blok, unpublished data). For each sample, five pots containing $500 \mathrm{ml}$ of soil were placed in a glasshouse at $20^{\circ} \mathrm{C}$ using a completely randomized design. In each pot, 50 rye plants (Secale cereale L. 'Petkus') were grown from seed to simulate the microbial recolonization of the soil that normally occurred during the period between removal of the plastic cover and planting of a susceptible crop. After 6 weeks, the rye was removed from the pots, the soil was screened through 2-mm openings, and pregerminated asparagus seeds were planted (three seeds per pot). After 16 weeks, root rot severity was assessed according to the scale described by Blok and Bollen (1).

Field experiment, 1995. The experiment was performed on a field situated close to the 1994 field. The soil was again a loamy sand ( $\mathrm{pH}-\mathrm{KCl} 6.5,3.4 \%$ organic matter). Most experimental details were the same as in 1994. Five blocks (replicates) instead of three were used, and the plot size was $6 \times 8 \mathrm{~m}$ (with the inner $2 \times$ $4 \mathrm{~m}$ used for pathogen samples and measurements). Soil physical and chemical parameter measurements were performed in plots of one block. Oxygen concentration of the soil atmosphere was measured in all plots of this block; the redox potential was measured in all covered plots and in the broccoli-amended, noncovered plot; and the soil temperature was measured in the covered and noncovered, broccoli-amended plots. In the plots where broccoli material was to be incorporated, 3-week-old broccoli plants (cv. Marathon) were transplanted on 19 June. Organic amendment was incorporated by rotary tilling on 19 July in amounts of $3.4 \mathrm{~kg}$ fresh weight $\mathrm{m}^{-2}$ $\left(0.3 \mathrm{~kg}\right.$ oven dry-weight $\left.\mathrm{m}^{-2}\right)$ and $4.0 \mathrm{~kg}$ fresh weight $\mathrm{m}^{-2}(0.5 \mathrm{~kg}$ oven dry-weight $\mathrm{m}^{-2}$ ), for broccoli and grass, respectively. In all plots, duplicate inoculum samples of $F$. oxysporum f. sp. asparagi, $R$. solani, and $V$. dahliae were buried at a depth of $15 \mathrm{~cm}$. After burial of samples and installation of thermocouples, Pt electrodes, and gas-diffusion chambers, the field was sprinkler irrigated on 20 July. On 21 July, the plastic cover was applied. As in 1994, noncovered plots were sprinkler irrigated when needed to prevent sand from blowing away. Weeds were controlled by one herbicide application (250 g of simazine and $400 \mathrm{~g}$ of diuron in 600 liters of water per ha). After 15 weeks, on 3 November, the plastic cover was removed, the pathogen samples were recovered, and survival was determined.

Data analysis. Prior to statistical analyses, data were checked for normality and homogeneity of variances, and transformed when needed. For the pathogen samples from the field experiment, the following transformations were used. A log transformation $\left(\log _{10}(x+1)\right)$ was applied to the data of $F$. oxysporum f. sp. asparagi (colony forming units per gram of soil), and a squareroot transformation $(\sqrt{ }(x+0.5))$ was applied to the data of $R$. solani (germination index) and $V$. dahliae (colony forming units per gram of soil). Analysis of variance was applied to test for main effects and interactions. Preplanned comparisons between treatment combinations were tested with linear contrasts (17). All analyses were performed using the Statistical Analysis System (version 6.04, SAS Institute Inc., Cary, NC). For presentation of the data on the survival of pathogens in the field experiments, backtransformed means were used.

\section{RESULTS}

Soil physical and chemical parameters. In both field experiments, the oxygen concentration of the soil atmosphere at a depth of $15 \mathrm{~cm}$ decreased rapidly to less than $1 \%$ in the covered plots, regardless of incorporation of organic amendment (Fig. 1). This means that most of the soil volume in the covered plots experienced complete anaerobiosis. In the nonamended, covered plots the concentration of oxygen started to increase gradually after 3 to 4 weeks. In the amended, covered plots, the concentration started to rise much later, after 7 to 8 weeks. In noncovered plots, concentrations were higher than in covered plots and fluctuated between 8 and $21 \%$ and between 18 and $21 \%$ in the 1994 and 1995 experiment, respectively.

In both experiments, the value of the redox potential in the amended, covered plots decreased rapidly and reached levels indicative of strongly reduced soil conditions (Fig. 2). In the 1994 experiment, the redox potential in the broccoli-amended, covered plot remained low for 7 weeks and decreased to a minimum of $-193 \mathrm{mV}$ on day 48 . In the nonamended, covered plot, the minimum redox potential value was $110 \mathrm{mV}$. It began to increase after 21 days. In the 1995 experiment, the redox potential in the nonamended, covered plot hardly decreased compared with the non-

TABLE 1. Analysis of variance and linear contrasts ${ }^{\mathrm{a}}$ for survival of Fusarium oxysporum $\mathrm{f}$. sp. asparagi, Rhizoctonia solani, and Verticillium dahliae after burial of inoculum samples in soil to a depth of $15 \mathrm{~cm}$ in the 1994 field experiment

\begin{tabular}{|c|c|c|c|c|c|c|c|}
\hline \multirow[b]{2}{*}{ Source } & \multirow[b]{2}{*}{ df } & \multicolumn{2}{|c|}{ F. oxysporum f. sp. asparagi } & \multicolumn{2}{|c|}{ R. solani } & \multicolumn{2}{|c|}{ V. dahliae } \\
\hline & & $\mathrm{MS}^{\mathrm{b}}$ & $P>F^{\mathrm{c}}$ & MS & $P>F$ & MS & $P>F$ \\
\hline Total (corrected) & 17 & 7.106 & & 4.032 & & 16,234 & \\
\hline Amendment (A) & 2 & 16.015 & $<0.001$ & 0.671 & 0.582 & 66,956 & 0.002 \\
\hline Plastic covering $(\mathrm{B})$ & 1 & 57.894 & $<0.001$ & 47.122 & $<0.001$ & 36,633 & 0.030 \\
\hline Blocks & 2 & 0.278 & 0.128 & 1.293 & 0.370 & 2,321 & 0.677 \\
\hline $\mathrm{A} \times \mathrm{B}$ & 2 & 14.616 & $<0.001$ & 2.875 & 0.136 & 21,788 & 0.059 \\
\hline Error & 10 & 0.109 & & 1.175 & & 5,722 & \\
\hline \multicolumn{8}{|l|}{ Linear contrasts } \\
\hline - Plastic: control versus amendment & 1 & 0.030 & 0.615 & 0.819 & 0.423 & 8,869 & 0.242 \\
\hline - Plastic: broccoli versus grass & 1 & 0.133 & 0.296 & 0.342 & 0.601 & 7,233 & 0.287 \\
\hline + Plastic: control versus amendment & 1 & 61.075 & $<0.001$ & 5.931 & 0.048 & 151,316 & $<0.001$ \\
\hline + Plastic: broccoli versus grass & 1 & 0.024 & 0.648 & 0.000 & 1.000 & 10,070 & 0.214 \\
\hline Control: - versus + plastic & 1 & $<0.001$ & 0.953 & 4.140 & 0.090 & 3,565 & 0.448 \\
\hline Broccoli: - versus + plastic & 1 & 44.941 & $<0.001$ & 21.484 & 0.002 & 35,328 & 0.032 \\
\hline Grass: - versus + plastic & 1 & 42.184 & $<0.001$ & 27.248 & 0.001 & 41,316 & 0.028 \\
\hline
\end{tabular}

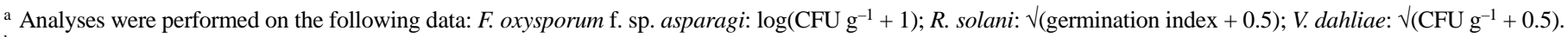

b Mean square.

c Probabilities associated with individual $F$ tests. 
covered plot. In the broccoli- and grass-amended, covered plots, the redox potential declined rapidly to a minimum of -13 and $-196 \mathrm{mV}$, respectively, then began to increase after day 11 . In the noncovered plots, the redox potential fluctuated only slightly in both experiments and ranged from 500 to $700 \mathrm{mV}$ (Fig. 2).

In both years, the experiments started in midsummer and lasted well into autumn. In 1994, the daily maximum soil temperature at $15 \mathrm{~cm}$ depth in the broccoli-amended, covered plot ranged between 25.6 and $32.6^{\circ} \mathrm{C}$ in the first 4 weeks and decreased gradually to $11^{\circ} \mathrm{C}$ at the end of the experiment. In the broccoli-amended, noncovered plot, the temperature was 6.6 to $0.4^{\circ} \mathrm{C}$ lower than in the covered plot. In 1995, the daily maximum soil temperature at $15 \mathrm{~cm}$ depth in the broccoli-amended, covered plot ranged between 29.4 and $39.0^{\circ} \mathrm{C}$ in the first 4 weeks and decreased gradually to $10^{\circ} \mathrm{C}$ at the end of the experiment. In the broccoli-amended, noncovered plot, the temperature again was 12.6 to $0.6^{\circ} \mathrm{C}$ lower than in the covered plot.

Survival of plant pathogens. Analysis of variance showed significant organic amendment-covering interactions for $F$. oxysporum f. sp. asparagi in 1994 and for all three fungal pathogens in 1995 (Tables 1 and 2). This indicates that the effect of covering depended on the organic-amendment treatment. Therefore, linear contrasts were calculated to test the effect of plastic cover for each organicamendment treatment and the effect of organic amendment for both plastic cover treatments (Tables 1 and 2).

Differences among the noncovered plots (i.e., nonamended control plots versus amended plots and broccoli-amended versus grassamended plots) were small and not significant in both experiments (Figs. 3 and 4, Tables 1 and 2). Large effects were observed for the covered plots. Application of plastic cover to the broccoli- and grass-amended plots resulted in strong inactivation of propagules of $F$. oxysporum f. sp. asparagi, $R$. solani, and $V$. dahliae compared with the nonamended, noncovered control. Where pathogen inactivation was not complete, it was generally more complete in the grass-amended than in the broccoli-amended plots, although this difference was significant $(P<0.05)$ only for $R$. solani in 1995. In the nonamended control plots of both experiments, application of plastic cover had no significant effect on survival of propagules of $F$. oxysporum f. sp. asparagi and $V$. dahliae. For $R$. solani, application of the plastic cover resulted in a lower survival in 1994 but in a higher survival in 1995.

Whereas in 1994 the variation among samples of the three fungal pathogens of the same treatment combination was small, it was large in 1995. In fact, strong reductions (similar to those in 1994) were observed in half of the samples and hardly any reduction was observed in the other samples. As a result, the trends in the results of both experiments were similar but the mean reductions found for propagules of $F$. oxysporum f. sp. asparagi, R. solani, and $V$. dahliae in the broccoli- and grass-amended, covered plots were larger in 1994 than in 1995.

Colonization of the soil by $\boldsymbol{F}$. oxysporum f. sp. asparagi. Moderate disease severity levels were found in the bioassay with the disease index ranging from 3.3 to 3.8 on a 0 to 10 scale, with only slight differences between treatment combinations. Analysis of variance for the disease-index data did not indicate significant main effects or interactions (data not shown).

\section{DISCUSSION}

Large and significant reductions in the number of viable survival structures were found for $F$. oxysporum f. sp. asparagi, $R$. solani, and $V$. dahliae in those plots where an organic amendment was incorporated and a plastic cover was applied compared with control plots. Application of a plastic cover or incorporation of an organic amendment alone did not result in significant reductions of viable propagules compared with the control. These results clearly show the potential of the combination of organic amendment and airtight plastic cover to control various persistent soilborne pathogens. The method might be deployed in high-value crops, such as asparagus, strawberry, and flower bulbs, and nursery crops, where the costs can be justified.

The mechanism of pathogen inactivation was not studied specifically in these experiments but, from the results obtained, indications can be inferred concerning the involvement of factors such as soil temperature, anaerobiosis, and crop-specific compounds. Direct thermal inactivation of pathogen propagules due to increased soil temperature under the plastic cover did not contribute significantly to pathogen inactivation in these experiments because pathogen inactivation was observed only in the amended, covered plots but not in the nonamended, covered plots. In the latter plots, the soil temperature was similar to that in the amended, covered plots. This implies that this method is essentially different from soil solarization, where lethal soil temperatures are crucial for pathogen control (6). However, the increase of soil temperature in the covered plots amended with plant material may well have contributed to pathogen inactivation by weakening survival structures. Weakening pathogen propagules by exposure to sublethal temperatures has been reported for several plant pathogens (3).

In covered plots, anaerobic conditions developed readily in both years, regardless of incorporation of organic amendment. The oxygen concentration of the soil atmosphere is determined by diffusion from adjacent noncovered soil and through the plastic cover

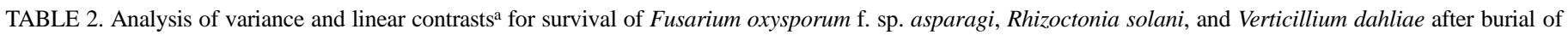
inoculum samples in soil to a depth of $15 \mathrm{~cm}$ in the 1995 field experiment

\begin{tabular}{|c|c|c|c|c|c|c|c|}
\hline \multirow[b]{2}{*}{ Source } & \multirow[b]{2}{*}{$\mathrm{df}^{\mathrm{b}}$} & \multicolumn{2}{|c|}{ F. oxysporum f. sp. asparagi } & \multicolumn{2}{|c|}{ R. solani } & \multicolumn{2}{|c|}{ V. dahliae } \\
\hline & & $\mathrm{MS}^{\mathrm{c}}$ & $P>F^{\mathrm{d}}$ & MS & $P>F$ & MS & $P>F$ \\
\hline Total (corrected) & 29 & 1.707 & $\ldots$ & 2.989 & & 0.673 & \\
\hline Amendment (A) & 2 & 3.924 & 0.040 & 11.723 & $<0.001$ & 3.289 & $<0.001$ \\
\hline Plastic covering (B) & 1 & 7.391 & 0.015 & 3.104 & $<0.107$ & 4.047 & $<0.001$ \\
\hline Blocks & 4 & 1.027 & 0.434 & 2.959 & 0.060 & 0.079 & 0.876 \\
\hline $\mathrm{A} \times \mathrm{B}$ & 2 & 4.742 & 0.023 & 12.545 & $<0.001$ & 1.627 & 0.009 \\
\hline Error & 20 & 1.033 & $\ldots$ & 1.085 & $\ldots$ & 0.266 & $\ldots$ \\
\hline \multicolumn{8}{|l|}{ Linear contrasts } \\
\hline - Plastic: control versus amendment & 1 & 0.058 & 0.816 & $<0.001$ & 0.989 & 0.351 & 0.264 \\
\hline - Plastic: broccoli versus grass & 1 & 0.004 & 0.954 & 0.050 & 0.832 & 0.005 & 0.896 \\
\hline + Plastic: control versus amendment & 1 & 14.557 & 0.001 & 36.085 & $<0.001$ & 8.515 & $<0.001$ \\
\hline + Plastic: broccoli versus grass & 1 & 2.712 & 0.121 & 9.222 & 0.009 & 0.962 & 0.072 \\
\hline Control: - versus + plastic & 1 & 0.596 & 0.457 & 6.350 & 0.026 & 0.033 & 0.729 \\
\hline Broccoli: - versus + plastic & 1 & 3.791 & 0.070 & 1.021 & 0.344 & 1.711 & 0.020 \\
\hline Grass: - versus + plastic & 1 & 12.488 & 0.002 & 20.826 & $<0.001$ & 5.557 & $<0.001$ \\
\hline
\end{tabular}

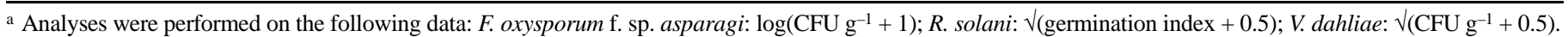

${ }^{\mathrm{b}}$ Due to missing values for $R$. solani, the degrees of freedom for total and error were lowered by 1 .

c Mean square.

${ }^{\text {d }}$ Probabilities associated with individual $F$ tests. 
and by consumption by the soil microflora and other oxidative processes. The rapid development of anaerobic conditions in the nonamended, covered plots indicates that the level of microbial respiration in these plots was relatively high in the first weeks. It was only after 3 to 4 weeks that the oxygen level increased in these plots, most probably as a result of a depletion of readily available nutrients, resulting in lower microbial activity and decreased soil respiration due to decreasing soil temperatures. In the amended, covered plots, anaerobic soil conditions continued because of the added organic amendment. The fact that in the nonamended, covered plots a 3- to 4-week period of anaerobiosis did not result in any inactivation of pathogens suggests that anaerobiosis in itself was not crucial to pathogen inactivation observed in the amended, covered plots. This is in accordance with the findings of Mitchell and Alexander (11), who studied the microbiology of flooded soils and with our own preliminary laboratory studies (W. J. Blok and G. C. M. Coenen, unpublished data).

Several authors reported inactivation of fungal pathogens by cruciferous tissues $(7,9,12,20)$. This inactivation has been attributed to toxic, volatile products of glucosinolates present in those amendments $(9,16)$. Subbarao et al. (20) disk-incorporated $11 \mathrm{~kg}$ of broccoli residues per $\mathrm{m}^{2}$ into field soil and found large reductions in the number of microsclerotia of $V$. dahliae and in Verticillium wilt severity, irrespective of tarping with 0.076 -mm-thick plastic. In the present study, incorporation of broccoli alone did not result in inactivation of pathogens. Possible reasons for the discrepancy
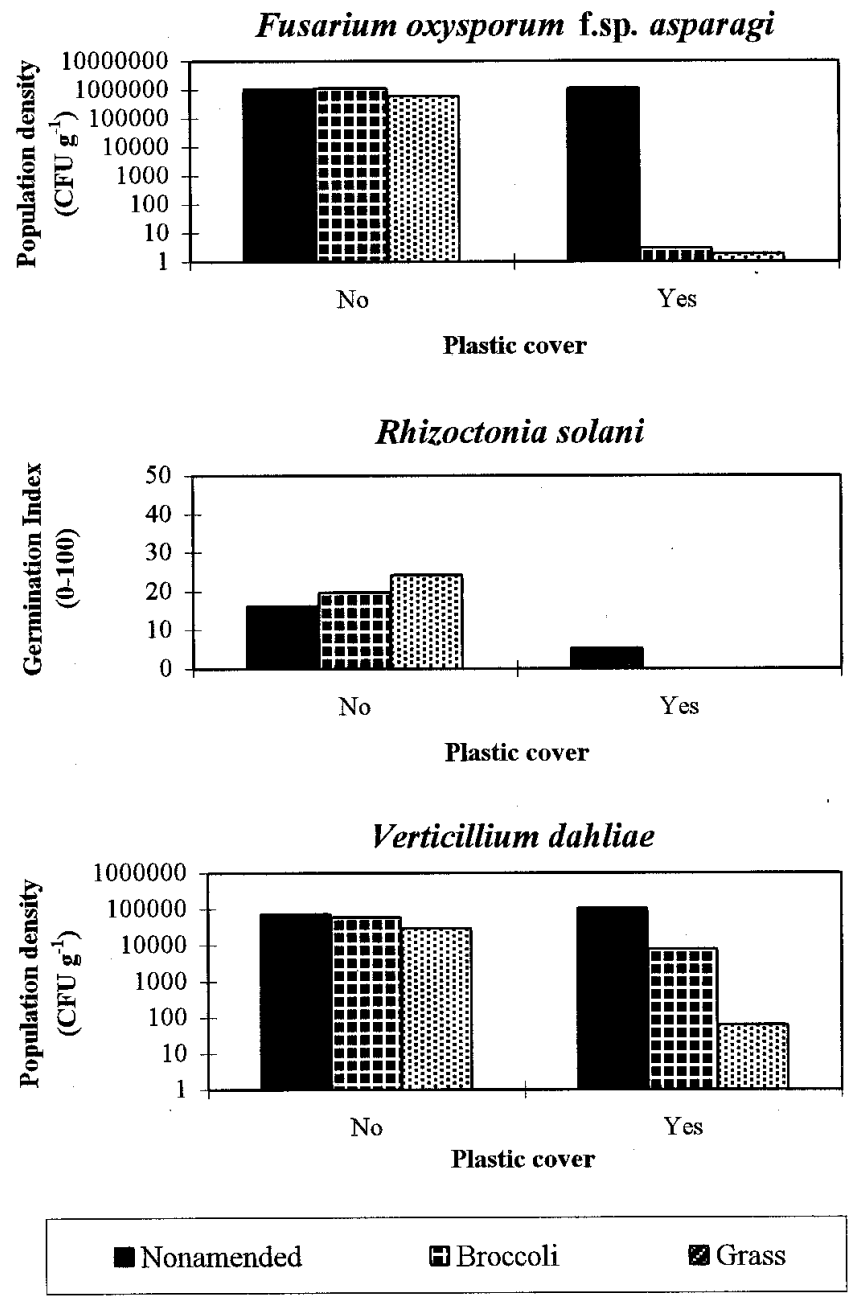

Fig. 3. Population density (Fusarium oxysporum f. sp. asparagi and Verticillium dahliae) and germination index (Rhizoctonia solani) in samples buried at a depth of $15 \mathrm{~cm}$ in the 1994 field experiment. The height of the bars represents backtransformed means. in control effects are differences in amount of tissue incorporated (e.g., Subbarao et al. [20] applied three times more broccoli residue than we did), and differences in content and type of glucosinolates in the plant material. It can be argued that, although these glucosinolate products were not effective in the broccoli-amended, noncovered plots, they might have contributed to pathogen inactivation in the covered plots; the concentration is expected to be higher there because the volatiles will be trapped under the plastic. This possibility cannot be completely ruled out. However, the fact that pathogens were inactivated in covered plots as effectively with grass as with broccoli suggests that it is more likely that crop-nonspecific fermentation products rather than crop-specific products are involved. This suggestion agrees with what has been found for flooded soils. In these soils the course of oxygen concentration and redox potential shows a pattern similar to those in the present study (15). It is reasonable to assume, therefore, that analogous mechanisms of pathogen inactivation are involved. Strong indications for a role of fermentation products in the inactivation of pathogens in flooded soil have been reported by several authors. Mitchell and Alexander (11) found that incorporation of readily metabolizable organic matter into flooded soil greatly accelerated the decline in numbers of propagules of $F$. oxysporum f. sp. conglutinans compared with nonamended flooded soil. The same was found by Menzies (10) for V. dahliae and by Watson (21) for Fusarium spp., $V$. dahliae, and Pyrenochaeta terrestris. Under reducing soil conditions, carbon dioxide, ethylene, hydrogen, methane,
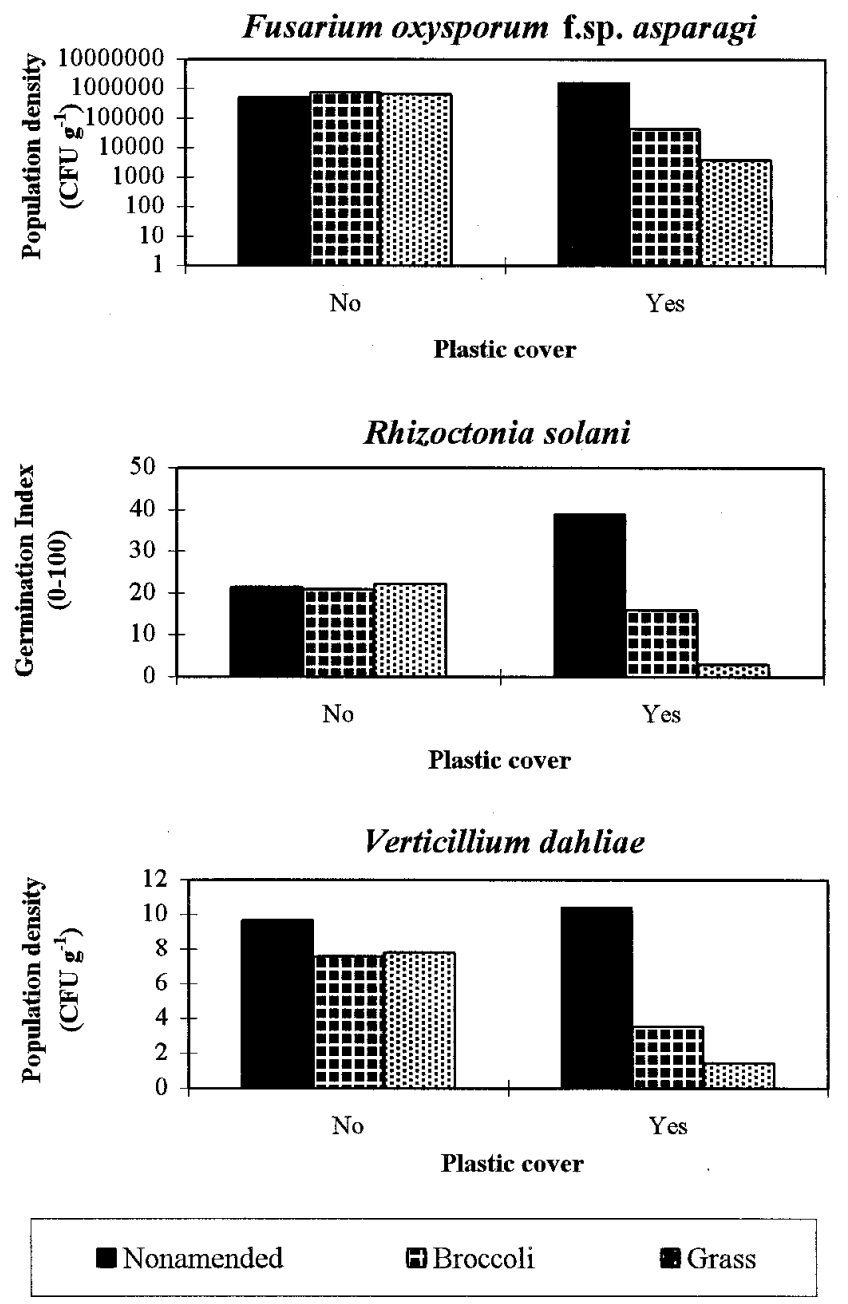

Fig. 4. Population density (Fusarium oxysporum f. sp. asparagi and Verticillium dahliae) and germination index (Rhizoctonia solani) in samples buried at a depth of $15 \mathrm{~cm}$ in the 1995 field experiment. The height of the bars represents backtransformed means. 
organic acids, alcohols, and aldehydes are among the compounds known to accumulate, at least temporarily (13). Several of these products are potentially fungitoxic and, therefore, may be involved in the inactivation of pathogens. However, studies relating concentrations of these products in soil to the inactivation of fungi are scarce. In addition, anaerobic microorganisms, including Bacillus and Clostridium spp., may affect plant pathogens because many of them are well-known antibiotic and toxin producers. Their contribution to pathogen inactivation in anaerobic soil sites is not well understood (2).

The amount of plant material incorporated was based on a freshweight basis. It turned out that the dry matter content of the plant materials was lower in 1995 than in 1994, resulting in lower amounts of organic matter incorporated in 1995. The latter implies that less substrate was available for the anaerobic microflora and that lower quantities of toxic fermentation products may have accumulated as well. This may explain the lower $E_{h}$ values and more variable pathogen inactivation observed in 1995. Differences in dry matter incorporated also may explain the slightly higher inactivation found in some cases for grass compared with inactivation for broccoli. These differences suggest that destruction of pathogen propagules can be optimized by incorporation of higher amounts of organic amendments than the $\approx 40 \mathrm{t} \mathrm{ha}^{-1}$ applied in the present study.

The induction of anaerobic and reducing soil conditions greatly disturbs the soil ecosystem. It is possible that this disturbance results in an increased conduciveness of the soil to certain pathogens, with the risk of rapid recolonization when part of the population survives the treatment or when infested material is introduced. An example of the latter has been observed in banana cultivation, where rapid recolonization by $F$. oxysporum $\mathrm{f}$. sp. cubense is one of the reasons that flooding is no longer used for control of this pathogen (18). However, we did not obtain evidence in this work for rapid recolonization of biologically disinfested soil by $F$. oxysporum f. sp. asparagi. Apparently, suppressiveness to $F$. oxysporum f. sp. asparagi was not affected by the amendment with broccoli in covered soil. Nevertheless, the experiences with banana and knowledge about the importance of soil fungistasis for the behavior of pathogens in soil (2) warrants further evaluation of this aspect under field conditions, especially for pathogens that exhibit a high competitive saprotrophic ability in soil. On the other hand, the disturbance of the soil ecosystem may also present opportunities for the introduction and establishment of populations of biocontrol agents, as proposed for soil solarization by Katan (6).

The prospects for control of persistent soilborne pathogens by combining incorporation of organic amendments with application of an airtight plastic cover have clearly been demonstrated. This approach may provide an alternative for chemical soil disinfestation for high-value crops under conditions where other alternatives, such as soil solarization or flooding, are not effective or not feasible.

\section{ACKNOWLEDGMENTS}

The project was supported financially by Asparagus B.V., Horst, the Netherlands. We thank J. Jeurissen and H. Verstegen of the Regional Research Centre Noord-Limburg at Horst for their skillful assistance and C. Slomp and M. J. Jeger, Department of Phytopathology, Wageningen
Agricultural University, for critical reading of the manuscript and valuable discussions.

\section{LITERATURE CITED}

1. Blok, W. J., and Bollen, G. J. 1995. Etiology of asparagus replant-bound early decline. Eur. J. Plant Pathol. 102:87-98.

2. Cook, R. J., and Baker, K. F. 1983. The Nature and Practice of Biological Control of Plant Pathogens. The American Phytopathological Society, St. Paul, MN.

3. DeVay, J. E., and Katan, J. 1991. Mechanisms of pathogen control in solarized soils. Pages 87-101 in: Soil Solarization. J. Katan and J. E. DeVay, eds. CRC Press, Boca Raton, FL.

4. Gamliel, A., and Stapleton, J. J. 1993. Characterization of antifungal volatile compounds evolved from solarized soil amended with cabbage residues. Phytopathology 83:899-905.

5. Harris, D. C., Yang, J. R., and Ridout, M. S. 1993. The detection and estimation of Verticillium dahliae in naturally infested soil. Plant Pathol. 42:238-250.

6. Katan, J. 1981. Solar heating (solarization) of soil for control of soilborne pests. Annu. Rev. Phytopathol. 19:211-236.

7. Kirkegaard, J. A., Wong, P. T. W., and Desmarchelier, J. M. 1996. In vitro suppression of fungal root pathogens of cereals by Brassica tissues. Plant Pathol. 45:593-603.

8. Komada, H. 1975. Development of a selective medium for quantitative isolation of Fusarium oxysporum from natural soil. Rev. Plant Prot. Res. 8:114-124.

9. Lewis, J. A., and Papavizas, G. C. 1971. Effect of sulfur-containing volatile compounds and vapors from cabbage decomposition on Aphanomyces euteiches. Phytopathology 61:208-214.

10. Menzies, J. D. 1962. Effect of anaerobic fermentation in soil on survival of sclerotia of Verticillium dahliae. (Abstr.) Phytopathology 52:743.

11. Mitchell, R., and Alexander, M. 1962. Microbiological changes in flooded soils. Soil Sci. 93:413-419.

12. Muelchen, A. M., Rand, R. E., and Parke, J. L. 1990. Evaluation of crucifer green manures for controlling Aphanomyces root rot of peas. Plant Dis. 74:651-654.

13. Ponnamperuma, F. N. 1972. The chemistry of submerged soils. Adv. Agron. 24:29-96.

14. Pullman, G. S., DeVay, J. E., and Garber, R. H. 1981. Soil solarization and thermal death: A logarithmic relationship between time and temperature for four soilborne plant pathogens. Phytopathology 71:959-964.

15. Reddy, K. R. 1987. The effect of flooding on physical, chemical, and microbiological properties of Histosols. Pages 7-22 in: Agricultural Flooding of Organic Soils. Bull. 870 Agric. Exp. Stn. Inst. Food Agric. Sci. G. H. Snyder, ed. University of Florida, Gainesville.

16. Smolinska, U., Morra, M. J., Knudsen, G. R., and Brown, P. D. 1997. Toxicity of glucosinolate degradation products from Brassica napus seed meal toward Aphanomyces euteiches f. sp. pisi. Phytopathology 87:77-82.

17. Sokal, R. R., and Rohlf, F. J. 1981. Biometry. 2nd ed. W. H. Freeman, New York.

18. Stover, R. H. 1979. Flooding of soil for disease control. Pages 19-28 in: Soil Disinfestation. D. Mulder, ed. Elsevier Scientific Publishing Company, Amsterdam.

19. Strandberg, J. O. 1987. The effect of flooding on plant pathogen populations. Pages 41-56 in: Agricultural Flooding of Organic Soils. Bull. 870 Agric. Exp. Stn. Inst. Food Agric. Sci. G. H. Snyder, ed. University of Florida, Gainesville.

20. Subbarao, K. V., Hubbard, J. C., and Koike, S. T. 1999. Evaluation of broccoli residue incorporation into field soil for Verticillium wilt control in cauliflower. Plant Dis. 83:124-129.

21. Watson, R. D. 1964. Eradication of fungi by a combination of crop residue, flooding, and anaerobic fermentation. (Abstr.) Phytopathology 54:14371438.

22. Zausig, J., 1995. Redox potential measurement. Pages 274-276 in: Methods in Applied Soil Microbiology and Biochemistry. K. Alef and P. Nannipieri, eds. Academic Press, London. 